\title{
CREB1 Gene
}

National Cancer Institute

\section{Source}

National Cancer Institute. CREB1 Gene. NCI Thesaurus. Code C38536.

This gene is involved in transcriptional regulation and its activity is modulated in response

to hormonal stimulation from the CAMP pathway. 